\title{
RELATIONSHIP OF VEGETABLE AND FRUIT CONSUMPTION WITH CENTRAL OBESITY IN ADULT IN PASAR IKAN COMMUNITY HEALTH CENTERS BENGKULU CITY IN 2018
}

\author{
Ketut Murni $^{1)}$, Desri Suryani1 ${ }^{1)}$, dan Tetes Wahyu W' \\ ${ }^{1}$ Jurusan Gizi, Poltekkes Kemenkes Bengkulu, Jl. Indragiri No. 03, Kota Bengkulu, 38225 \\ E-mail: Ketutmurni97@gmail.com
}

Submited: 9 October 2019 ; Accepted: 10 October 2019

https://doi.org/10.36525/sanitas.2019.8

\begin{abstract}
Adulthood was where the nutritional needs of the adult age changed according to the age group. Lifestyle changes, in accordance with the changes in diet from traditional food to modern food habits led to overweight and obesity. The purpose of this study was to determine the relationship of vegetable and fruit consumption with the incidence of central obesity in adults in Pasar Ikan Bengkulu Health Center of Bengkulu City in 2018. This research was descriptive research with cross-sectional approach. The location of this research was in Pasar Ikan Bengkulu Health Center of Bengkulu City. The technique sampling was using simple random sampling with 74 sampel. The data was collected by using interview and FFQ semi kuantitatif, then analyzed by univariate and bivariate. The results of this research were $82,4 \%$ for vegetable consumption which was included in poor category, $55.4 \%$ fruit consumption which was included in good category and $78.4 \%$ for waist circumference which was included in central obesity, it was tested by using chi square test. The result showed that there was no relationship between the habits of consuming vegetables with the incidence of central obesity $(\rho>0.05)$ and there was no association between the habits of consuming fruit with the incidence of central obesity $(\rho>0.05)$. It was important to provide counseling about the importance of eating fruits and vegetables so the obese can always control their weight and add insight to constantly adjust their diet.
\end{abstract}

Keywords: Vegetables consumption, Fruits consumption and central obesity

\section{HUBUNGAN KONSUMSI SAYUR DAN BUAH DENGAN KEJADIAN OBESITAS SENTRAL PADA DEWASA DI PUSKESMAS PASAR IKAN KOTA BENGKULU TAHUN 2018}

\begin{abstract}
ABSTRAK
Masa dewasa merupakan dimana kebutuhan gizi pada usia dewasa berubah sesuai dengan kelompok usia tersebut. Perubahan gaya hidup, terkait dengan perubahan pola makan dari tradisional ke kebiasaan makanan modern menyebabkan terjadinya overweight dan obesitas. Tujuan dari penelitian ini adalah untuk mengetahui hubungan konsumsi sayur dan buah dengan kejadian obesitas sentral pada dewasa di Puskesmas Pasar Ikan Kota Bengkulu. Penelitian ini merupakan penelitian deskriptif dengan pendekatan cross-sectional. Penelitian dilakukan di Puskesmas Pasar Ikan Kota Bengkulu pada bulan April. Pengambilan sampel dilakukan dengan teknik simple random sampling sebanyak 74 sampel. Data dikumpulkan melalui wawancara dan FFQ semi kuantitatif dianalisis secara univariat dan bivariat. Hasil penelitian menunjukkan konsumsi sayur hampir seluruh kategori kurang (82,4\%), konsumsi buah 55,4\% kategori baik dan lingkar pinggang 78,4\% kategori obesitas sentral. Tidak ada hubungan antara konsumsi sayur dengan kejadian obesitas sentral $(\mathrm{p}>0,05)$ dan tidak ada hubungan antara konsumsi buah dengan kejadian obesitas sentral $(\mathrm{p}>0,05)$. Perlu diberikan penyuluhan tentang pentingnya makan sayur dan buah sehingga penderita obesitas dapat selalu mengontrol berat badan dan menambah wawasan untuk selalu mengatur pola makannya.
\end{abstract}

Kata Kunci: Konsumsi sayur, konsumsi buah dan obesitas sentral 


\section{PENDAHULUAN}

Masa dewasa merupakan dimana kebutuhan gizi pada usia dewasa berubah sesuai dengan kelompok usia tersebut. Peranan gizi pada usia dewasa terutama adalah untuk mencegah dan meningkatkan kesehatan, mencegah penyakit, dan menghambat perkembangan penyakit degeneratif. Susunan makanan yang dapat mengoptimalkan kesehatan gizi jangka panjang adalah dengan menerapkan pola makan seimbang, beraneka ragam, rendah lemak terutama lemak jenuh dan banyak mengkonsumsi sayur dan buah Obesitas cenderung meningkat pada populasi dewasa. Sekitar $80-90 \%$ kasus obesitas diperkirakan ditemukan pada rentang usia dewasa. ${ }^{5}$ Berbagai penelitian menunjukkan golongan umur 20 sampai 64 tahun berisiko terkena obesitas.

Faktor terkait dengan kejadian obesitas meliputi faktor lingkungan dan sosial, gangguan sistem syaraf dan endokrin, faktor gaya hidup, konsumsi makanan tinggi lemak, konsumsi makanan berlebihan, umur, faktor psikologi/stres, perilaku merokok, dan konsumsi alkohol. ${ }^{16}$

Faktor langsung yang menyebabkan obesitas sentral yaitu makanan dan minuman manis, makanan tinggi lemak, serta kurang mengonsumsi sayur dan buah dengan mengonsumsi sayur dan buah seseorang bisa menurunkan berat badan karena sayur dan buah merupakan sumber antioksidan dan fitokimia dan jika dikonsumsi memiliki kalori rendah. ${ }^{3}$

Buah merupakan sumber yang baik dari antioksidan dan fitokimia seperti vitamin C, karoten, flavonoid, dan polifenol buah mengandung sejumlah gula alamiah, seperti fruktosa dan glukosa mengonsumsi buah secara teratur dan tidak berlebihan dapat mengontrol nafsu makan dan menurunkan berat badan, sayuran juga menyumbang sejumlah vitamin, mineral, serta larut dan tidak larut, karbohidrat, protein, lemak dan berbagai nutrisi dalam sehari-hari. 4

Konsumsi sayur dan buah diperlukan tubuh sebagai sumber vitamin, mineral dan serat dalam mencapai pola makan sehat sesuai anjuran pedoman gizi seimbang untuk kesehatan yang optimal. ${ }^{12}$ Sayur dan buah memiliki energi yang rendah dan merupakan sumber serat dan mikronutrien seperti vitamin dan mineral. Berdasarkan Riskesdas 2013, anjuran untuk mengonsumsi sayur dan buah adalah minimal 5 porsi/hari namun proporsi kurang makan 
sayur dan buah di Indonesia sangat tinggi sebanyak 93,6 \% sedangkan di Kota Bengkulu proporsi makan buah dan sayur 5 porsi/ hari tinggi sebanyak 3,2. ${ }^{13}$

Hasil Survei Konsumsi Makanan Individu (SKMI) dalam Studi Diet Total (SDT) 2014 bahwa konsumsi penduduk terhadap sayur dan olahannya serta buah dan olahannya masih tergolong rendah. ${ }^{12}$ Kebutuhan sayur dan buah sesuai berat porsi yang dianjurkan Pedoman Gizi Seimbang menurut kelompok umur yaitu, anjuran konsumsi sayur dan buah untuk kelompok usia dewasa dan lansia 400-600 gr/hr yang terdiri dari 250 gram sayur (setara dengan 2 porsi atau 2 gelas sayur setelah dimasak dan ditiriskan) dan 150 gram buah (setara dengan 3 buah pisang ambon ukuran sedang atau 1 potong pepaya ukuran sedang atau 3 buah jeruk ukuran sedang).

Permasalahan utama yang dihadapi dalam konsumsi buah dan sayur adalah bahwa secara nasional konsumsi buah dan sayur penduduk Indonesia masih berada di bawah konsumsi yang dianjurkan. Hasil penelitian Hermina dan Prihatini (2016) sebanyak 97,1\% penduduk Indonesia kurang mengonsumsi sayur dan buah. Kelompok umur yang kurang mengonsumsi sayur dan buah kelompok dewasa (96,9\%). Penelitian Hermina dan Prihatini (2016) Sebanyak 97,1\% penduduk Indonesia kurang mengonsumsi sayur dan buah. Kelompok umur yang kurang mengonsumsi sayur dan buah kelompok dewasa $(96,9 \%) .{ }^{8}$

Hasil penelitian Esmaillzadeh et al, (2006) menunjukkan bahwa asupan buah dan sayur yang lebih tinggi berhubungan dengan rendahnya risiko sindrom metabolik. Obesitas, khususnya obesitas abdominal dan salah satu komponen penting untuk mendiagnosanya adalah lingkar pinggang. ${ }^{7,10}$

Berdasarkan Riskesdas (2013) secara nasional, prevalensi obesitas sentral mencapai $26.6 \%$ pada usai dewasa. Sedangkan di Kota Bengkulu prevalensi obesitas sentral meningkat di tahun 2013 yaitu sebesar 37,4\% dan prevalensi obesitas sentral berdasarkan karakteristik umur 25-34 sebesar 26,5\%, 35-34 sebesar 32,4\%, 45-54 sebesar 33,2 \%, 55-54 sebesar 27,9 $\%$. Prevalensi obesitas sentral atau terendah di temui di Kabupaten Seluma $(12,5 \%)$ dan tertinggi di Kota Bengkulu (37,4\%). ${ }^{13}$

Berdasarkan data yang diperoleh di Provinsi Bengkulu tahun 2016 dari 5 Kabupaten prevalensi obesitas sebesar 24\% sedangkan di Kota Bengkulu sebesar 60,31\%. Di Puskesmas Pasar Ikan jumlah usia 25-64 tahun sebesar 281 orang. ${ }^{14}$ 
Berdasarkan survei pendahuluan yang dilakukan terhadap 10 dewasa usia 25-64 tahun di Puskesmas Pasar Ikan dilakukan pengukuran Lingkar Pinggang (LP) didapatkan hasil pengukuran Lingkar Pinggang (LP) dari 8 sampel melebihi dari $>80 \mathrm{~cm}$ untuk perempuan dan Lingkar Pinggang (LP) laki-laki melebihi > $90 \mathrm{~cm}$ dengan konsumsi sayur dan buahnya dari 10 sampel hanya 2 sampel ( 1 laki-laki dan 1 perempuan mengonsumsi buah sesuai dengan anjuran yaitu $\geq 150$ gram sedangkan mengonsumsi sayur di bawah dari anjuran yaitu $<250$ gram.

Berdasarkan uraian tersebut, peneliti tertarik untuk melakukan penelitian mengenai hubungan konsumsi sayur dan buah dengan kejadian obesitas sentral pada dewasa di Puskesmas Pasar Ikan Kota Bengkulu Tahun 2018.

\section{METODE PENELITIAN}

Penelitian ini menggunakan pendekatan cross sectional. Dilaksanakan pada bulan April 2018. Populasi dalam penelitian ini adalah semua laki-laki dan perempuan usia 25-64 tahun di Puskesmas Pasar Ikan Kota Bengkulu yaitu sebanyak 281 orang dengan populasi obesitas sentral berjumlah 224 orang sedangkan pada populasi non obesitas sentral berjumlah 57 orang. Sampel dalam penelitian ini berjumlah 74 orang dengan sampel obesitas 58 orang. Teknik pengambilan sampel dengan cara simple random sampling. Variabel yang diteliti yaitu konsumsi sayur dan buah dan obesitas sentral. Konsumsi sayur dan buah dengan wawancara menggunakan form FFQ semi kuantitatif serta obesitas sentral dengan pengukuran lingkar pinggang menggunakan pita seca. Analisis statistik menggunakan uji chi square.

\section{HASIL}

Tabel 1. Distribusi Frekuensi Konsumsi Sayur dan Buah Pada Dewasa di Puskesmas Pasar Ikan Tahun 2018.

\begin{tabular}{llcc}
\hline No & \multicolumn{1}{c}{ Variabel Penelitian } & N & $\%$ \\
\hline \multirow{2}{*}{1} & Konsumsi Sayur & & \\
& Kurang & 61 & 82,4 \\
& Baik & 13 & 17,6
\end{tabular}




\begin{tabular}{lcc}
\hline Kurang & 33 & 44,6 \\
Baik & 41 & 55,4 \\
Lingkar Pinggang & 58 & 78,4 \\
Obesitas Sentral & 16 & 21,6 \\
Tidak Obesitas Sentral & 74 & 100 \\
\hline Jumlah & & \\
\hline
\end{tabular}

Tabel 1 menunjukkan konsumsi sayur 82,4\% dalam kategori kurang, konsumsi buah 55,4\% dalam kategori baik dan lingkar pinggang 78,4\% kategori obesitas sentral.

Tabel 2. Hubungan Konsumsi Sayur dengan Obesitas Sentral pada Dewasa di Puskesmas Pasar Ikan Kota Bengkulu Tahun 2018

\begin{tabular}{|c|c|c|c|c|c|c|c|}
\hline \multirow{3}{*}{$\begin{array}{c}\text { Konsumsi } \\
\text { sayur }\end{array}$} & \multicolumn{4}{|c|}{ Lingkar Pinggang } & \multirow{2}{*}{\multicolumn{2}{|c|}{ Total }} & \multirow[t]{3}{*}{$\rho$-value } \\
\hline & \multicolumn{2}{|c|}{ Obesitas sentral } & \multicolumn{2}{|c|}{$\begin{array}{c}\text { Tidak Obesitas } \\
\text { sentral }\end{array}$} & & & \\
\hline & $\mathrm{n}$ & $\%$ & $\mathrm{n}$ & $\%$ & $\mathrm{n}$ & $\%$ & \\
\hline Kurang & 48 & 78,7 & 13 & 21,3 & 61 & 100 & 0,572 \\
\hline Baik & 10 & 76,9 & 3 & 23,1 & 13 & 100 & \\
\hline Jumlah & 58 & 78,4 & 16 & 21,6 & 74 & 100 & \\
\hline
\end{tabular}

Tabel 2 menunjukkan dari 61 konsumsi sayur yang kurang pada responden terdapat 48 orang $(78,7 \%)$ dengan status gizi obesitas sentral dan dari 13 konsumsi sayur yang baik pada responden terdapat 10 orang $(76,9 \%)$ dengan status gizi obesitas sentral.

Tabel 3. Hubungan Konsumsi Buah dengan Obesitas Sentral pada Dewasa di Puskesmas Pasar Ikan Kota Bengkulu Tahun 2018

\begin{tabular}{|c|c|c|c|c|c|c|c|}
\hline \multirow{3}{*}{$\begin{array}{l}\text { Konsumsi } \\
\text { Buah }\end{array}$} & \multicolumn{4}{|c|}{ Lingkar Pinggang } & \multirow{2}{*}{\multicolumn{2}{|c|}{ Total }} & \multirow[t]{3}{*}{$\rho$-value } \\
\hline & \multicolumn{2}{|c|}{ Obesitas sentral } & \multicolumn{2}{|c|}{$\begin{array}{l}\text { Tidak Obesitas } \\
\text { sentral }\end{array}$} & & & \\
\hline & $\mathrm{n}$ & $\%$ & $\mathrm{n}$ & $\%$ & $\mathrm{n}$ & $\%$ & \\
\hline Kurang & 28 & 84,8 & 5 & 15,2 & 33 & 100 & 0,353 \\
\hline Baik & 30 & 73,2 & 11 & 26,8 & 41 & 100 & \\
\hline Jumlah & 58 & 78,4 & 16 & 21,6 & 74 & 100 & \\
\hline
\end{tabular}


Tabel 3 menunjukkan dari 33 konsumsi buah yang kurang pada responden terdapat 28 orang $(84,3 \%)$ dengan status gizi obesitas sentral dan dari 41 responden yang konsumsi buah yang baik ditemukan 30 orang $(73,2 \%)$ dengan status gizi obesitas sentral.

\section{PEMBAHASAN}

\section{Konsumsi Sayur}

Berdasarkan hasil penelitian tidak ada hubungan antara konsumsi sayur dengan kejadian obesitas sentral pada dewasa di Puskesmas Pasar Ikan Kota Bengkulu Tahun 2018 dengan $\rho$-value 0,572 . Dalam studi lain analisis cross-sectional dari 11.707 orang dewasa di Eropa prevalensi obesitas dan obesitas sentral dievaluasi dengan diet tradisional dan khusus dalam dua kelompok Meksiko; hasil penelitian menunjukkan bahwa diet tradisional yang kaya buah-buahan dan sayuran secara signifikan tidak berkorelasi dengan lingkar pinggang (LP) sehingga menekankan pentingnya mengganti beberapa senyawa diet dengan makanan tersebut dan produk kaya serat, yang dapat membantu untuk menghindari penambahan berat badan. $^{2}$

Berdasarkan hasil penelitian, menunjukkan bahwa konsumsi sayur pada responden masih kurang dibandingkan dengan anjuran standar konsumsi sayur per hari menurut Pedoman Gizi Seimbang yaitu 400 gram per orang per hari yang terdiri dari 250 gram sayur. Hal ini sejalan dengan penelitian Hermina dan Prihatini (2016) yang menunjukkan bahwa 97,1\% penduduk Indonesia kurang mengonsumsi sayur dan buah pada kelompok dewasa yang kurang mengonsumsi sayur sebesar 96,9\%. Hasil Survei Konsumsi Makanan Individu (SKMI) bahwa konsumsi penduduk terhadap sayur dan olahannya masih tergolong rendah. Faktor kebiasaan dan ekonomi dapat menjadi alasan rendahnya konsumsi sayur pada responden. Selain itu, budaya pada masyarakat menganggap bahwa dalam sekali makan cukup dengan mengonsumsi makanan pokok dan lauk saja, sedangkan sayur hanya dianggap sebagai makanan tambahan, bukan sebagai makanan utama yang harus dipenuhi dan dikonsumsi setiap hari. ${ }^{8,12}$

Konsumsi sayur dan buah yang belum memadai berpengaruh terhadap vitamin, mineral serta serat yang sangat dibutuhkan oleh tubuh. Masih tingginya masalah gizi di 
masyarakat diduga berkaitan dengan pola konsumsi makanan di masyarakat yang belum sesuai dengan lifestyle dan gaya hidup sehat pada berbagai kelompok umur, terutama pola makan dalam konteks gizi seimbang. ${ }^{12}$

Sayur merupakan suatu kelompok pangan yang mengandung berbagai zat gizi (vitamin dan mineral), serat, serta senyawa fitokimia yang sangat dibutuhkan dan bermanfaat bagi kesehatan tubuh dan salah satu sumber serat terbesar dibanding pangan lainnya. Serat memiliki manfaat yang berpengaruh bagi kesehatan tubuh, seperti mekanismenya dalam penurunan asupan energi, pengurangan asupan total yang disebabkan lamanya waktu mengunyah dan menelan, serta meningkatkan motilitas, pengosongan lambung dan usus, dan mengurangi absorbsi, menambahkan bahwa konsumsi serat mengurangi rasa lapar dan meningkatkan rasa kenyang. ${ }^{4}$

Konsumsi sayur sangat penting dalam kehidupan sehari-hari karena berfungsi sebagai zat pengatur, mengandung zat gizi seperti vitamin dan mineral, memiliki kadar air tinggi, sumber serat makanan, antioksidan. Sayuran merupakan sumber serat yang baik karena terdapat serat yang larut air (pektin) dan serat yang tidak larut air seperti selulosa. Sayur dengan warna hijau memiliki kandungan air yang sangat tinggi, kandungan energi yang rendah serta mikronutrien yang relatif tinggi. ${ }^{22}$

Penyebab obesitas karena gaya hidup tidak sehat, genetik dan pengaruh lingkungan. Menurut Miller, Moore, \& Kral, (2011) pola makan yang tidak sehat dan kurangnya konsumsi sayur. ${ }^{15}$ Rendahnya konsumsi sayuran karena individu memilih suatu makanan tertentu, yang dipengaruhi faktor individual dan kolektif. Secara individual terdapat ketertarikan terhadap makanan (food preference) berdasarkan selera, rasa, dan pengalaman. ${ }^{17}$

Kurangnya konsumsi sayur dapat mengakibatkan berbagai dampak yaitu memicu perkembangan obesitas karena merupakan makanan yang rendah energi dan kaya akan serat yang akan menghambat terjadinya penimbunan lemak pada tubuh sehingga menyebabkan obesitas. Kurang mengkonsumsi sayur dapat mengakibatkan tubuh kekurangan zat gizi seperti vitamin, mineral dan serat sehingga menimbulkan terjadinya berbagai penyakit contohnya penyakit degeneratif yang pada umumnya disebabkan oleh kegemukan dan penyakit saluran pencernaan. ${ }^{9}$ 
Faktor-faktor yang mempengaruhi konsumsi sayur pada dewasa. Penelitian Rasmussen et al (2006) menyimpulkan bahwa terdapat beberapa faktor determinan yang berhubungan konsumsi sayur yaitu faktor usia, jenis kelamin, sosial ekonomi, preferensi/kesukaan makan dan ketersediaan sayur di rumah. ${ }^{18}$

\section{Konsumsi Buah}

Berdasarkan hasil penelitian tidak ada hubungan antara konsumsi sayur dengan kejadian obesitas sentral pada dewasa di Puskesmas Pasar Ikan Kota Bengkulu Tahun 2018 dengan $\rho$ value 0,353 .

Konsumsi responden terhadap buah $(55,4 \%)$ lebih baik daripada konsumsi sayur. Konsumsi buah yang cukup seharusnya dapat mencegah dari kegemukan namun ada beberapa sampel dengan konsumsi cukup buah namun memiliki berat badan gemuk. Hal ini dapat disebabkan karena konsumsi buah dalam bentuk lain seperti jus. Dari hasil wawancara FFQ semi kuantitatif responden mengatakan selain mengonsumsi buah potong juga mengonsumsi buah dalam bentuk jus. Ketiadaan hubungan antara konsumsi buah dengan kegemukan salah satunya dapat disebabkan oleh konsumsi buah dalam bentuk jus hal ini dikarenakan dalam jus diberi penambahan gula sekitar 1-2 penukar. Dengan demikian buah yang awalnya rendah energi menjadi tinggi energi dengan penambahan gula.

Penelitian Esmaillzadeh dan Azadbakht (2008) pada perempuan Iran, menunjukkan bahwa seseorang yang memiliki pola makan yang sehat disertai asupan serat tinggi memiliki kemungkinan yang lebih kecil untuk mengalami obesitas umum dan obesitas sentral. ${ }^{5}$ Selain sayur, buah-buahan juga merupakan jenis pangan sumber serat. Hasil uji statistik menunjukkan tidak terdapat hubungan yang signifikan antara konsumsi buah dengan obesitas sentral $(\mathrm{r}=-0.063, \mathrm{p}=0.543){ }^{7}$ Hasil penelitian ini sejalan dengan Diana et al (2013) menunjukkan bahwa tidak adanya hubungan antara konsumsi buah dengan kejadian obesitas sentral diduga karena konsumsi buah kurang sebesar 97.9\%, serta karena kandungan serat dari buah yang dikonsumsi seperti apel, mangga, pisang, jeruk, dan papaya tidak mencukupi kebutuhan. Menurut Rozaline (2006) kandungan serat makanan pada sayuran lebih banyak dibandingkan pada buah-buahan. ${ }^{19}$ 
Konsumsi buah yang rendah merupakan faktor risiko terhadap penyebab obesitas sentral dapat terjadi karena perilaku dan gaya hidup, perilaku makan serta faktor sosial ekonomi. Salah satu penyebab terbesar dari obesitas adalah perubahan dalam pola makan dan pola hidup yang menjadi lebih kebarat-baratan (western). Pola makan yang kebarat-baratan biasanya miskin serat dimana sebagian besar penduduk Indonesia memiliki konsumsi serat yang rendah yaitu sebanyak $80 \%$ penduduk Indonesia mengkonsumsi serat $=15$ gram/orang/hari. Hasil penelitian Dewi, 2002 mengatakan bahwa semakin rendah konsumsi serat maka semakin tinggi terjadinya obesitas. ${ }^{6}$

Buah mengandung serat, vitamin, mineral dan air. Komponen terbesar buah-buahan adalah air. Oleh karena itu, kandungan serat pangan yang terdapat dalam buah-buahan rendah. Kandungan serat pangan dalam buah-buahan yang terbesar yaitu senyawa pektin dan lignin. Selain sebagai sumber serat pangan, buah-buahan juga merupakan sumber vitamin yang sangat baik (khususnya vitamin B dan C) dan mineral. ${ }^{1}$

Beberapa penelitian yang telah dilakukan untuk menemukan faktor-faktor yang mempengaruhi perilaku konsumsi buah pada masyarakat. Penelitian yang dilakukan oleh Story (2002) ditemukan konsumsi buah pada masyarakat dipengaruhi oleh 4 faktor yaitu faktor individu (pengetahuan dan alasan seseorang mengonsumsi buah), faktor lingkungan sosial (keluarga), faktor lingkungan fisik dan faktor media massa ( pemasaran). ${ }^{20}$

Faktor selain buah yang dapat menyebabkan terjadinya obesitas sentral antara lain karakteristik demografi dan sosial-ekonomi, gaya hidup. Karakteristik demografi dan sosialekonomi meliputi umur, jenis kelamin, status pernikahan, besar keluarga, pendidikan, pekerjaan dan pengeluaran per kapita.

Obesitas sentral lebih banyak terjadi pada orang dewasa. Semakin meningkatnya umur, maka semakin tinggi risiko terjadinya obesitas sentral. Umur merupakan faktor prediksi dari terjadinya obesitas sentral. ${ }^{21}$ Kecenderungan obesitas dialami oleh seseorang yang berumur lebih tua diduga akibat lambatnya metabolisme, rendahnya aktivitas fisik, seringnya frekuensi konsumsi pangan, dan kurangnya perhatian pada bentuk tubuhnya. ${ }^{11}$

\section{KESIMPULAN}

Berdasarkan hasil penelitian dapat disimpulkan bahwa hampir seluruh konsumsi sayur pada dewasa kategori kurang dan sebagian dari konsumsi buah pada dewasa kategori baik. 
Tidak ada hubungan konsumsi sayur dan buah dengan kejadian obesitas sentral pada dewasa ditandai dengan hasil ( $\rho$-value $>0,05)$.

\section{UCAPAN TERIMA KASIH}

Penulis mengucapkan terima kasih kepada pembimbing dan penguji yang telah memberikan saran yang bersifat membangun sehingga KTI ini dapat diselesaikan dan kepada orang tua yang telah memberikan dukungan dan dana pada penelitian ini.

\section{DAFTAR PUSTAKA}

1. Astawan, M, dan T. Wresdiyati. Diet Sehat dengan Makanan Berserat. Solo: Tiga Serangkai Pustaka Mandiri; 2004.

2. Bes-Rastrollo M, Martínez-González MA, dkk. Association of fiber intake and fruit/vegetable consumption with weight gain in a Mediterranean population. Nutrition. 2006.

3. Burhan, F. Z, Sirajuddin, S. dan Indriasari, R. Pola Konsumsi Terhadap Kejadian Obesitas Sentral pada Pegawai Pemerintahan di Kantor Bupati Kabupaten Jeneponto. Artikel Penelitian. Program Studi Ilmu Gizi Fakultas Kesehatan Masyarakat Universitas Hasanudin Makasar. 2013; 1-14.

4. Dalimartha S, Andrian F. Fakta Ilmiah Buah dan Sayur. Jakarta. 2013.

5. David, J. Wellness Concepts and Applications, 3rd.ed. United States of America: Hoffman Press; 2000.

6. Dewi, Emy S. Hubungan Antara Konsumsi Lemak Dan Serat Dengan Status Gizi. Semarang: UNES. 2002.

7. Esmaillzadeh A, Masoud K, dkk. Fruit and vegetable intakes, C-reactive protein, and the metabolic syndrome. Amerika. Journal of Clinical Nutrition. 2017; 1489-97.

8. Hermina dan Prihatini S. Gambaran Konsumsi Sayur dan Buah Penduduk Indonesia dalam Konteks Gizi Seimbang: Analisis Lanjut Survei Konsumsi Makanan Individu (SKMI) 2014. Jakarta: Buletin Penelitian Kesehatan. 2016; Vol. 44, No. 3: 205-18.

9. Jahari \& Sumarno. Epidemiologi Konsumsi Serat Di Indonesia. Puslitbang Gizi Depkes RI; 2001.

10. Jalal F, Lupito NI, Susanti N, Oenzil F. Hubungan lingkar pinggang dengan kadar gula darah, trigliserida dan tekanan darah pada etnis Minang di Kabupaten Padang Pariaman, Sumatera Barat. Padang: Fakultas Kedokteran, Universitas Andalas. 2006; 1-23.

11. Kantachuvessiri A, Sirivichayakul C, KaewKungwal J, Tungtrongchitr R, Lotrakul M. Factors associated with obesity among workers in a metropolitan 50 waterworks authority. Southeast Asian J Trop Med Public Health. 2005; 36:1057- 1065.

12. Kementerian Kesehatan RI, Pedoman Gizi Seimbang. Jakarta : Kementerian Kesehatan RI; 2014. 
13. Kementerian Kesehatan RI, Riset Kesehatan Dasar. Jakarta : Kementerian Kesehatan RI; 2013.

14. Kementerian Kesehatan RI, Riskesdas Dalam Angka Provinsi Bengkulu. Jakarta : Kementerian Kesehatan RI; 2013.

15. Miller., Moore., \& Kral. Children's daily fruit and vegetable intake: Associations with maternal intake and child weight status. Journal of Nutrition Education and behavior. $2011 ; 1-5$.

16. Mukherjee B, Hossain CM, Mondal L, Paul P, and Ghosh MK. Review: Obesity and insulin resistance: an abridged molecular correlation. Lipid Insights. 2013; 1-11.

17. Raine, K. D. Determinants of healthy eating in Canada. Centre for Health Promotion Studies, University of Alberta. 2005.

18. Rasmussen, M., Kloner, R., Klepp, K., Lytle, L., Brug, J., Bere, E., Due, P. Determinants of Fruit and Vegetable Consumption Among Children and Adolescents: A Review of The Literature. Part I: Quantitative Studies. International of Behavioral Nutrition and Physical Activity. 2006; 3(22): 1-19.

19. Rozaline H, Sekarindah T. Terapi Jus Buah dan Sayur. Depok (ID): Niaga Swadaya; 2006.

20. Story, M., Sztainer, DN., French, S. Individual and environmental influence on adolescent eating behaviors. Journal of the America Dietetic Association. 2002; 102 (3): 40-51.

21. Veghari, G. Sedaghat, M. Joshaghani, H., dkk. The Prevalence And Associated Factors Of Central Obesity In Northem Iran. Iranian Cardiovascular Research Journal. 4:4. 2010; 164-68.

22. Yuliarti, Nurheti. Food Suplement: Panduan Mengonsumsi Makanan Tambahan Untuk Kesehatan Anda. Yogjakarta: Banyu Media; 2008. 